Jurnal Ilmu Sosial Volume 19 | Issue 1 | June 2020 | Page 58-91

Available online at JIS website: https://jis.undip.ac.id

Research Article

\title{
Village Community Readiness In Estabilishing A Global Village
}

Received: $14^{\text {th }}$ May 2020; Revised: $17^{\text {th }}$ August 2020;

Accepted: 20 ${ }^{\text {th }}$ August 2020; Available online: $24^{\text {th }}$ August 2020

\section{Eny Boedi Orbawati, Sujatmiko, Fadlurrahman, Nike Mutiara Fauziah}

Department of Public Administration, Faculty of Social and Political Sciences, Universitas Tidar, Jl. Kapten Suparman, Magelang City, 56116, Indonesia

\begin{abstract}
Global village is a phenomenon that occurs due to advances in information technology where there are no physical boundaries between individuals, communities, and countries. The world is connected through information technology and shares a variety of things. Apart from being a potential threat, the global village phenomenon also provides opportunities for introducing the Indonesian tourism sector to the global community. One of the villages that have the potential to exploit the global village phenomenon, especially in the tourism sector, is Ngargogondo Village, Borobudur Subdistrict, Magelang Regency, Central Java because it has the potential as a language tourism village. This study aims to measure community readiness in realizing a global village in the tourism sector with an analysis of community readiness dimensions in tourism and the global village aspect. This study used a survey approach with 157 respondents who were obtained using cluster random sampling technique. Meanwhile, the indicators used are adopted from the Tri-Ethnic for Prevention Research, with 19 indicators as research instruments. The results showed that the Ngargogondo Village community's readiness was at the preparation stage (tourism aspect) and pre-planning (global village aspect). This study suggests that to increase community readiness in realizing the global village tourism sector, the Ngargogondo Village government must increase the availability of resources, especially in the tourism aspect, and create a positive climate in the community in response to the development of information technology in Ngargogondo Village.
\end{abstract}

Keywords: Global Village; Community Readiness; Language Tourism Village; Ngargogondo Village

How to Cite: Orbawati, E.B., Sujatmiko, Fadlurrahman, Fauziah, N.M. (2020). Village Community Readiness In Establishing A Global Village. Jurnal Ilmu Sosial, 19 (1): 58-91 (doi: 10.14710/jis.19.1.2020.58-91), [Online]

Permalink/DOI: https://doi.org/10.14710/jis.19.1.2020.58-91

Corresponding Author: fadlurrahman@untidar.ac.id (Fadlurrahman) 


\section{INTRODUCTION}

The Global Competitiveness Index (GCI) has been used as a measure to determine one country's level of progress compared to other countries. This index is carried out primarily to measure the level of productivity of a country's policies, both institutionally and substantially. Moreover, the community of nations is increasingly open due to advances in communication technology known as the global village. Globalization and the Era of the Industrial Revolution 4.0 have become a necessity that a country must face. The inexistence of boundaries in the global village phenomenon can threaten countries that are not ready to face this phenomenon. It is not easy to gather, manage, and take advantage of the country's potential to compete on the world stage, as Indonesia is currently facing.

Despite being a threat, the global village phenomenon also provides an opportunity to introduce the Indonesian tourism sector to the global community. One of the ten National Strategic Tourism Areas in the Government Regulation of the Republic of Indonesia Number 50 of 2011 concerning the Master Plan for National Tourism Development 2010-2025 is the Borobudur Area and the surrounding village areas as a tourist village. A tourist village or tourist destination village is a village that integrates tourist attractions, public facilities, tourism facilities, and accessibility designed in a structure of community life that integrates with the prevailing procedures and traditions (Law Number 10 of 2009).

The wealth of natural and cultural resources in rural areas has a strong potential to increase the country's competitiveness starting from the village. One of the villages in the Borobudur area that has the potential and opportunity to take advantage of the global village phenomenon in the tourism sector is Ngargogondo Village, Borobudur Subdistrict, Magelang Regency. Based on data from the Village Building Index (VBI) of Ngargogondo Village in 2019, Access to Information and Communication in Ngargogondo Village can be seen in Table 1. 
Table 1. Village Measurement (VBI) 2019

\begin{tabular}{|c|c|c|c|}
\hline No & Questionnaire Questions of VBI & Provider/ & Output \\
\hline \multirow[t]{5}{*}{1} & Cellphone/handphone signal in the village & & \\
\hline & $\begin{array}{l}\text { a. Telkomsel cell phone operator/provider can re- } \\
\text { ceive signals }\end{array}$ & Telkomsel & $\checkmark$ \\
\hline & $\begin{array}{l}\text { b. Indosat cell phone operator/provider can receive } \\
\text { signals }\end{array}$ & Indosat & $\checkmark$ \\
\hline & $\begin{array}{l}\text { c. XL cell phone operator/provider can receive } \\
\text { signals }\end{array}$ & XL Axiata & $\checkmark$ \\
\hline & $\begin{array}{l}\text { d. Other cell phone operators/providers can receive } \\
\text { signals }\end{array}$ & Other provider & Tri \\
\hline 2 & $\begin{array}{l}\text { National TVRI and regional TVRI channel television } \\
\text { programs }\end{array}$ & TVRI & $\checkmark$ \\
\hline 3 & Private channel television programs & Private channels & $\checkmark$ \\
\hline 4 & Foreign channel television programs & Foreign channels & $\checkmark$ \\
\hline 5 & Internet facility at the village head office is available & Internet & $\checkmark$ \\
\hline 6 & Villagers have internet access & Internet Cafe & $\checkmark$ \\
\hline \multirow[t]{3}{*}{7} & a. Village Information on the Information Board & Information Board & $\checkmark$ \\
\hline & b. Village Information Website & Village Website & $\checkmark$ \\
\hline & c. Other means of information & Other medium & Videotron \\
\hline
\end{tabular}

Source: Village Building Index (VBI) form of Ngargogondo Village, 2019

Based on these data, Ngargogondo Village has the potential as a tourism village that will be recognized by the global community through its access to information and communication capital. In addition to access to information and communication, Ngargogondo Village has the potential for Language Village tourism as an educational tour, which can be seen through the website in Figure 1. 


\section{Jurnal Ilmu Sosial Volume 19 | Issue $1 \mid$ June 2020 | Page 58-91}

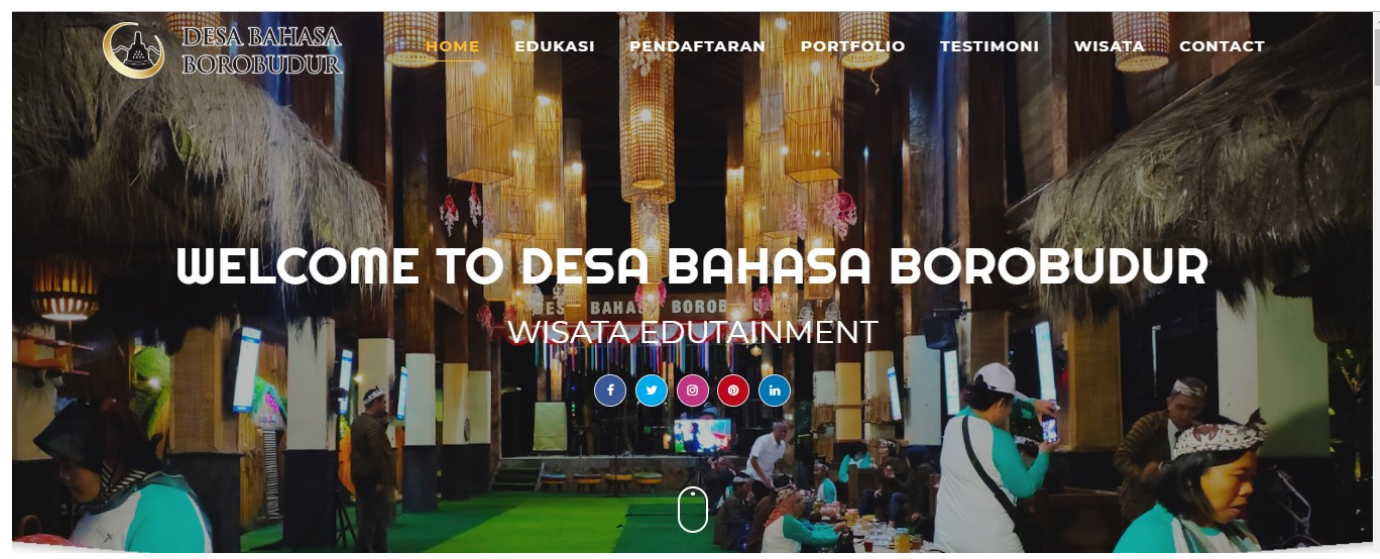

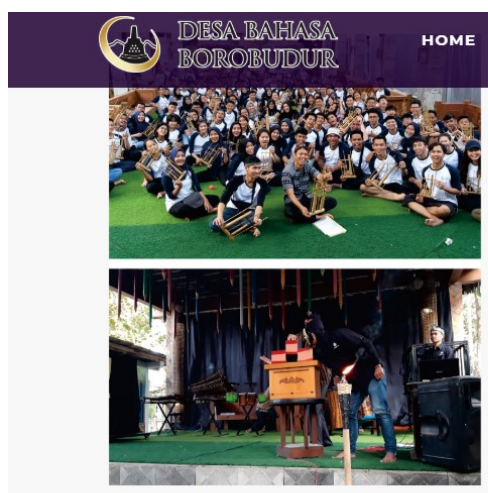

Wisata Edutainment

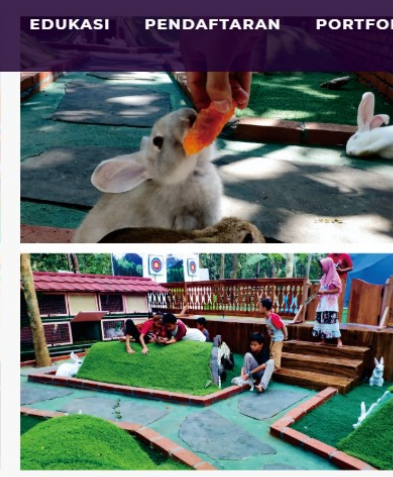

Wisata Taman Kelinci

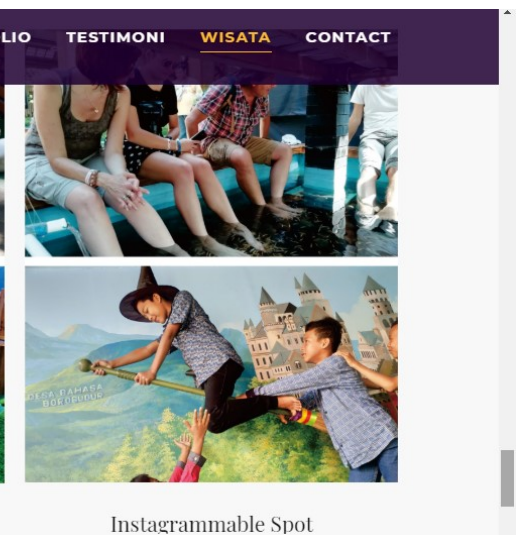

Instagrammable Spot

Figure 1. Homepage of Borobudur Language Village Website

Source: www.desa-bahasa.com, 2019

Ngargogondo Language Village contains an educational package combined with tour activities around the Borobudur area for visitors. Not only for visitors, but the establishment of the Borobudur Language Village is also aimed at making the villagers into a global community capable of interacting and communicating in various languages. This goal is to support the Ngargogondo Village residents to easily communicate with tourists from various countries, considering that tourists visiting Borobudur come from various nationalities with various languages.

The establishment of the Ngargogondo Language Village was made possible by the local community who support government programs in the tourism sector. Community support is highly dependent on the readiness they have. In other words, there must be community support if the government, private sector, or organizations are to implement their policies effectively. Community readiness is a concept that can be measured, either at the individual or community level, which functions to measure how well an individual or community, is prepared to deal with an issue at hand (Tri-Ethnic Center for Prevention Research, 2014). To obtain community's 


\section{Jurnal Ilmu Sosial Volume 19 | Issue 1| June 2020 | Page 58-91}

support, policymakers must understand the level of readiness of the community as affected parties. Therefore, research on community readiness is substantial to carry out. This condition motivates the researchers to conduct research related to the study of the readiness of the Ngargogondo Village community. This study aims to determine the level of readiness of the Ngargogondo Village community in realizing a global village in the tourism sector and to find out which dimensions have the highest and lowest values.

There are three arguments why research on community readiness in realizing the global village of the tourism sector in Ngargogondo Village, Borobudur Subdistrict, Magelang Regency is essential: First, the problem of developing a tourist village as an effort to improve the quality of life for the maximum welfare of rural communities in the context of national development is problems that are macro because the village is a system that is directly related to the structure of the Unitary State of the Republic of Indonesia (Maschab, 2013). The global village phenomenon can be an opportunity if the problems of village development in the tourism sector, which have contributed to national development, can be resolved.

Second, rural communities, as subjects affected by government policies in the tourism sector, have a vital function in supporting tourism development in the village. Various facts show that the readiness of the community to support village development still needs serious attention. Nevertheless, community readiness is the most significant factor in determining whether a policy can be implemented effectively (Edwards et al., 2000). Third, the village as a street-level of bureaucracy can be seen as a miniature state. Village competitiveness describes the stae's competitiveness because by building villages, it also builds Indonesia's competitiveness (Prasetyono, 2017).

Edwards et al. (2000) stated that readiness is the biggest factor in determining whether a program can be implemented effectively with the community's support. To generate this support, the program provider must know the extent of the community's readiness as the program recipient. This readiness is useful for determining the right treatment to be applied in a particular community, and what steps the community should take to implement various programs or policies.

In psychology, readiness is defined as the level of development of human maturity to practice something (Chaplin, 2006). Readiness is a condition in which an individual has reached a particular stage linked to physical, psychological, spiritual, and skill maturity (Yusnawati, 2007). Readiness is also defined as a person's competence to execute something and respond to the situation faced in a certain way (Arikunto, 2001; Slameto, 2010; Ramadhan; 2015). 


\section{Jurnal Ilmu Sosial Volume 19 | Issue 1| June 2020 | Page 58-91}

Readiness is a basic foundation or capital for individuals, communities, and governments in following up on activities that will be carried out in the future (Wahyuni, 2005 in Kurniati, et al., 2014).

Readiness is a concept that can be measured both at the individual or community level. This measurement serves to measure how far the individual or community is prepared to address an issue (Tri-Ethnic Center for Prevention Research, 2014). The community readiness measurement tool, namely the community readiness model, has been widely used in various kinds of research, both in the fields of education, health, media, and social politics (Waryanto and Insani, 2013; Slater et al., 2005; Thurman et al., 2003; Ramadhan, 2015; Boquiren, 2018). Pentz in Nugraha and Mahida (2013) states that the community readiness model serves to determine the community's response to project program/policy interventions.

This study summarizes the various dimensions of community readiness used as an instrument to determine the community's readiness in the research location. The synthesis of the dimensions is presented in Table 2.

Table 2. Synthesis Dimensions of Community Readiness

\begin{tabular}{ll}
\hline \multicolumn{1}{c}{ Dimension } & \multicolumn{1}{c}{ Description } \\
\hline $\begin{array}{l}\text { Community knowledge about } \\
\text { the issue/problem }\end{array}$ & $\begin{array}{l}\text { Understanding of the existing issues/problems (causes, } \\
\text { consequences, impacts) }\end{array}$ \\
$\begin{array}{l}\text { Community knowledge of ef- } \\
\text { forts (including prevention) }\end{array}$ & $\begin{array}{l}\text { Understanding of the efforts that have been made to ad- } \\
\text { dress the issue/problem, including prevention efforts (and } \\
\text { the effectiveness of its achievement) }\end{array}$ \\
Community efforts/existing pre- & $\begin{array}{l}\text { The existence of programs, activities, and policies that are } \\
\text { vention efforts }\end{array}$ \\
used to address issues/problems \\
Attitudes and roles of leaders/influential people in the \\
community in dealing with issues/problems \\
The general attitude of the community in dealing with is- \\
sues/problems \\
Availability of resources in dealing with issues/problems \\
(financial, human resources, facilities, etc.)
\end{tabular}

Source: Adopted and processed from Tri-Ethnic Center (2014); Edwards et al. (2000); Plested et al. (2006) 


\section{Jurnal Ilmu Sosial Volume 19 | Issue 1| June 2020 | Page 58-91}

The Community Readiness Model has nine levels of community readiness starting from the lowest level to the highest level. This level will also indicate the extent to which the community is prepared to carry out a program or policy. The level of community readiness is presented in Table 3.

Table 3. Level or Stage of Community Readiness

\begin{tabular}{|c|c|c|}
\hline No & Level/Stage & Description \\
\hline 1 & No awareness & $\begin{array}{l}\text { The community or chairperson does not recognize the issue as a } \\
\text { problem. }\end{array}$ \\
\hline 2 & Denial/resistance & $\begin{array}{l}\text { Some people know there is an issue, but most deny that the issue } \\
\text { that arises is their problem. }\end{array}$ \\
\hline 3 & Vague awareness & $\begin{array}{l}\text { A small proportion of community members are aware of the is- } \\
\text { sues at hand. However, there is no direct motivation to do } \\
\text { anything. }\end{array}$ \\
\hline 4 & Preplanning & $\begin{array}{l}\text { The community is aware of the problem and realizes something } \\
\text { must be done about it; there is even a special group dealing with } \\
\text { the problem. However, efforts are still not detailed and focused, } \\
\text { such as inadequate planning. }\end{array}$ \\
\hline 5 & Preparation & $\begin{array}{l}\text { Leaders are active in addressing existing issues. Planning is done } \\
\text { seriously, and the focus is detailed. }\end{array}$ \\
\hline 6 & Initiation & $\begin{array}{l}\text { Sufficient information is clearly available to justify follow-up } \\
\text { efforts (activities, actions, policies, etc.). Action has started and } \\
\text { is ongoing, but it is still an initial act. }\end{array}$ \\
\hline 7 & Stabilization & $\begin{array}{l}\text { Several activities and action programs have been implemented } \\
\text { and supported by policymakers. Several community members are } \\
\text { trained and experienced. The community climate supports the } \\
\text { ongoing process at this stage. }\end{array}$ \\
\hline 8 & $\begin{array}{l}\text { Confirmation/ } \\
\text { expansion }\end{array}$ & $\begin{array}{l}\text { Standard efforts have been made. The public and those in au- } \\
\text { thority support the increase of various efforts. Community } \\
\text { members feel comfortable using existing services, data can be } \\
\text { regularly retrieved, and previous decisions are evaluated and } \\
\text { modified. }\end{array}$ \\
\hline
\end{tabular}




\begin{tabular}{lll}
\hline No & Level/Stage & \multicolumn{1}{c}{ Description } \\
\hline 9 & High level of com- & The community has detailed knowledge of the general issues, \\
munity ownership/ & causes, consequences, and risks to the existing problems. Some \\
professionalization & $\begin{array}{l}\text { community members are highly trained and active, the leaders } \\
\text { are fully supportive, community participation is very high, and } \\
\text { the problem solving is done professionally. }\end{array}$ \\
& &
\end{tabular}

Source: Adopted and processed from Tri-Ethnic Center (2014); Edwards et al. (2000); Plested et al. (2006)

"Such is the character of a village or, since electric media, such is also the character of global village" (McLuhan, 1962). A piece of the quote is a sentence in McLuhan's book that has the form "The making of typographic man," which begins a discussion of the global village concept. McLuhan introduced the global village concept around the 60s. The term global village is intended for a phenomenon currently happening where information in other parts of the world can be known in real-time due to developments in information technology. Technological developments have contributed to the creation of a global village. "The term global village to epitomize the age of electric information in which we currently reside" (Johnson, 2000). The embryo of the global village is marked by the formation of electronic media, especially media that connect people. Electronic media is seen as a 'catalyst' towards a global village that is interconnected, organic, and holistic (Michael, 1999). McLuhan stated that

"Technologies are extensions of human physical and mental capacities; the wheel is an extension of the foot, the book an extension of the eye, and electric circuitry an extension of the central nervous system. When the central nervous system is distributed in a global embrace through electronic technologies, awareness of others is heightened and humans return to tribal conditions" (Gibson and Murray, 2012).

Electronic media plays a vital role in the creation of a global village, one of which is television and radio. As stated by Michael (1999), the more people who watch television, the bigger and faster the emergence of a global village. The world becomes small and without limit under the conditions of the development of electronic media technology; whatever happens to anyone, happens to everyone (Molinaro et al., 1987). 


\section{Jurnal Ilmu Sosial Volume 19 | Issue $1 \mid$ June 2020 | Page 58-91}

The development of the internet and new electronic-based media, therefore emphasizes the relevance of the global village existence (Press, 1995).

Global village is a metaphor that connects every individual, community, and country in the world into a 'village' by the development and movement of electronic media, thus naturally giving birth to a global village (Johnson, 2000; Magio, 2008). In a global village, space and time no longer exist, or in other words there are no boundaries (Gibson and Murray, 2012). "Human can no longer live in isolation but will always be connected by electronic media that is instant and sustainable. Electronic media has the ability to bridge cultures that had never been able to communicate before this connection" (Andung, et al., 2018).

In reality, people who live in a village are connected and share feelings with each other as a unit under the term village as a place. The same condition applies in the global village community. However, what brings together the global village community is information technology through electronic media where people live in the imagination of common space, namely the global village (Pamungkas, 2015). Thus, the existence of electronic media is the basis for the formation of a global village. In this study, understanding or awareness of the use of information technology through electronic media among the community is important to form a global village. The goal is to increase the economy through the tourism sector by managing and utilizing local resources in the village where the research is located (Ngargogondo Village).

One of the efforts to improve rural communities' economy is through tourism development by utilizing local resources. This effort was made because the tourism sector is an instrument in improving the community's quality of life (Kismartini et al., 2018). If managed properly, the tourism sector can reduce poverty and improve the welfare of rural communities. However, not all people are ready to manage their resources or accept a program/policy. Therefore, measurement and analysis must be carried out in advance to determine the level of community readiness.

On the one hand, studies on community readiness always focus on specific issues, especially research articles. Several previous studies discussed community readiness by focusing on environmental management and tourism, implementation of industrial estate policies and technology, social health, and youth violence (Muhammad, 2015; Phon-ngam, 2014; Indiarti and Munir, 2016; Wijaya et al., 2020; Sugiharto et al., 2018; Ramadhan, 2015; Nugraha and Mahida, 2013; Paltzer et al., 2013; Shadowen et al., 2017). Furthermore, community preparedness is used as a tool to explore barriers to addressing reduced alcohol use among adolescents (Kelly and Stanley, 2014). On the other hand, the global village study in several previous articles has been 


\section{Jurnal Ilmu Sosial Volume 19 | Issue $1 \mid$ June 2020 | Page 58-91}

termed a metaphor and phenomenon to discuss various things such as globalization, digitization, the value of multiculturalism, community traditions, and poverty in various countries, various ethnic groups, and various people with different views who are members of a community.

This study is different from the studies mentioned above. The novelty of this research lies in the focus of the study, which is to collaborate between community readiness studies and global village studies in the context of tourism. Although Muhammad (2015), Phon-ngam (2014), Indiarti and Munir (2016), Sugiharto et al. (2018), and Wijaya, et al. (2020) have discussed community readiness in the context of tourism, they do not mention global village in their research. In addition, our research discusses global village as a phenomenon explained in terms of technological development and assesses community's readiness in developing and using technology so that the global village phenomenon can be significantly operationalized in further research.

\section{RESEARCH METHOD}

This study used a survey approach with 157 respondents (10\% of sample size) obtained using cluster random sampling technique according to community livelihoods, including farmers (91 people), farm laborers (30 people), doctors ( 1 person), PNS (3 people), private employees (1 person), self-employed ( 27 people), army ( 2 people), and police ( 2 people). Operationally, this study assesses community's readiness from two aspects, namely the tourism and global village aspects. The dimensions used to assess community's readiness in these two aspects use the dimension of the community readiness model as a research variable. There are 19 research indicators adopted from the Tri-Ethnic for Prevention Research (2014), which functions as a data collection instrument for the tourism aspect (first aspect) and global village aspect (second aspect). The research variables and indicators are presented in Table 4. 
Table 4. Research Variables and Indicator

\begin{tabular}{|c|c|}
\hline Variable & Indicator (tourism and global village) \\
\hline \multirow[t]{4}{*}{$\begin{array}{l}\text { Community Knowledge } \\
\text { about the Issue (CKI) }\end{array}$} & $\begin{array}{l}\text { Basic knowledge related to the Language Village tourism pro- } \\
\text { gram and technology development in Ngargogondo Vil- } \\
\text { lage. }\end{array}$ \\
\hline & $\begin{array}{l}\text { Knowledge of the availability of general information related to } \\
\text { the Language Village tourism program and the develop- } \\
\text { ment of information technology in Ngargogondo Village. }\end{array}$ \\
\hline & $\begin{array}{l}\text { Knowledge of the availability of detailed information related to } \\
\text { the Language Village tourism program and the develop- } \\
\text { ment of information technology in Ngargogondo Village. }\end{array}$ \\
\hline & $\begin{array}{l}\text { Knowledge of access to information related to the Language } \\
\text { Village tourism program and the development of infor- } \\
\text { mation technology in Ngargogondo Village. }\end{array}$ \\
\hline \multirow[t]{3}{*}{$\begin{array}{l}\text { Community Knowledge of } \\
\text { Efforts (CKE) }\end{array}$} & $\begin{array}{l}\text { Basic knowledge of the efforts to implement the Language Vil- } \\
\text { lage tourism program and the development of information } \\
\text { technology in Ngargogondo Village. }\end{array}$ \\
\hline & $\begin{array}{l}\text { General knowledge of the efforts to implement the Language } \\
\text { Village tourism program and the development of infor- } \\
\text { mation technology in Ngargogondo Village. }\end{array}$ \\
\hline & $\begin{array}{l}\text { Detailed knowledge of the efforts to implement the Language } \\
\text { Village tourism program and the development of infor- } \\
\text { mation technology in Ngargogondo Village. }\end{array}$ \\
\hline
\end{tabular}




\section{Jurnal Ilmu Sosial Volume 19 | Issue 1| June 2020 | Page 58-91}

Variable

Community Efforts /

Existing Prevention

Efforts (CE)

Leadership (L)

Community Climate

(CC)
Indicator (tourism and global village)

The existence of efforts to implement the Language Village tourism program and information technology development in Ngargogondo Village.

The continuity of efforts to implement the Language Village tourism program and the development of information technology in Ngargogondo Village.

The existence of a plan to develop efforts to implement the

Language Village tourism program and the development of information technology in Ngargogondo Village.

The existence of a policy for implementing the Language Village tourism program and the development of information technology in Ngargogondo Village.

The awareness of village leaders regarding the Language Village tourism program and the development of information technology in Ngargogondo Village.

Support from village leaders regarding the Language Village tourism program and information technology development in Ngargogondo Village.

The involvement of village leaders regarding the Language Village tourism program and the development of information technology in Ngargogondo Village.

Community attitudes regarding the Language Village tourism program and the development of information technology in Ngargogondo Village.

The existence of various kinds of community support related to the Language Village tourism program and the development of information technology in Ngargogondo Village. 


\section{Jurnal Ilmu Sosial volume 19 | Issue 1| June 2020 | Page 58-91}

Variable

Indicator (tourism and global village)

Resources (R)

The absence of village resources related to the Language Village tourism program and the development of information technology in Ngargogondo Village.

Reluctance to allocate village resources related to the Language Village tourism program and the development of information technology in Ngargogondo Village.

The need to maximize village resources related to the Language Village tourism program and the development of information technology in Ngargogondo Village.

Source: Tri-Ethnic Center, 2014

The data analysis was carried out in a descriptive quantitative manner based on the TriEthnic for Prevention Research (2014) with two stages. The first stage is an analysis of the value/score of each dimension/variable, while the second stage is an analysis of the level of community readiness using the following formula (Kurniati et al., 2014):

$$
\mathrm{PKM}=(\mathrm{K} 1+\mathrm{K} 2+\mathrm{K} 3+\mathrm{K} 4+\mathrm{K} 5+\mathrm{K} 6) / 6
$$

Description: PKM : Score/community readiness level

K1 : Community knowledge on the issue

K2 : Community knowledge on the efforts

K3 : Community efforts

K4 : Leadership

K5 : Community climate

K6 : Resources 


\section{Jurnal Ilmu Sosial Volume 19 | Issue $1 \mid$ June 2020 | Page 58-91}

\section{RESULTS AND DISCUSSION}

Language Village is a term for a village that has language advantages compared to other villages. Parakan Hamlet in Ngargogondo Village was used as a pioneering location for the Language Village as an English language courses center. Ngargogondo Language Village was established in 1998, but in the process, it experienced ups and downs so that from 2007 to 2011, the Ngargogondo Language Village did not have any learning activities. Language Village started to rise and be rebuilt in 2011 with a new concept that has been adjusted so that the learning process becomes faster, easier, and more fun.

Based on the type of area, Ngargogondo has the potential for abundant natural resources. Ngargogondo Village offers a beautiful panorama of the incised mountains. This beautiful environmental condition supports six hamlets, namely Malangan, Wagean, Kujon, Parakan, Kuncen, and Ngargosari hamlets to be the proper locations to be developed into Tourism Village with their respective potentials. In addition, various types of home industries in the culinary field or homestays have been established for tourists. Based on these various potentials it has, Ngargogondo Village has the potential to become a developed tourism village by utilizing the global village phenomenon and the support community's readiness.

Several community readiness studies that focus on the tourism sector use a different dimension of analysis to our research. Research from Wijaya et al. (2020) and Indiarti and Munir (2016) use the socio-economic, socio-cultural, environmental, and management dimensions to assess the community's readiness, especially community-based tourism. Phon-ngam (2014), on the other hand, uses the dimensions of the availability of accommodation, tourism activities, the availability of information centers, and resources. Meanwhile, our research uses dimensions in the community readiness model (CRM) adopted from the Tri-Ethnic for Prevention Research, which follows other studies but has a different focus, namely public knowledge about issues, community knowledge about efforts, community efforts, leadership, community climate, and resources (Thurman et al., 2003; Slater et al., 2005; McElroy et al., 2011; Paltzer et al., 2013; Ramadhan, 2015; Waryanto and Insani, 2013; Kurniati et al., 2014; Kostadinov et al., 2015; Boquiren, 2018; Islam et al., 2019). 


\section{Jurnal Ilmu Sosial Volume 19 | Issue 1| June 2020 | Page 58-91}

\section{Analysis of Community Readiness Dimensions}

\section{a. Community Knowledge on the Issue}

We use four indicators to operationalize the dimensions of community knowledge about the issue of the language village program (tourism aspect) and the global village, including basic knowledge of to the program, general information knowledge of the program, detailed information knowledge of the program, and knowledge access to information of the program as shown in $\quad$ Figure (Plested et 2006).

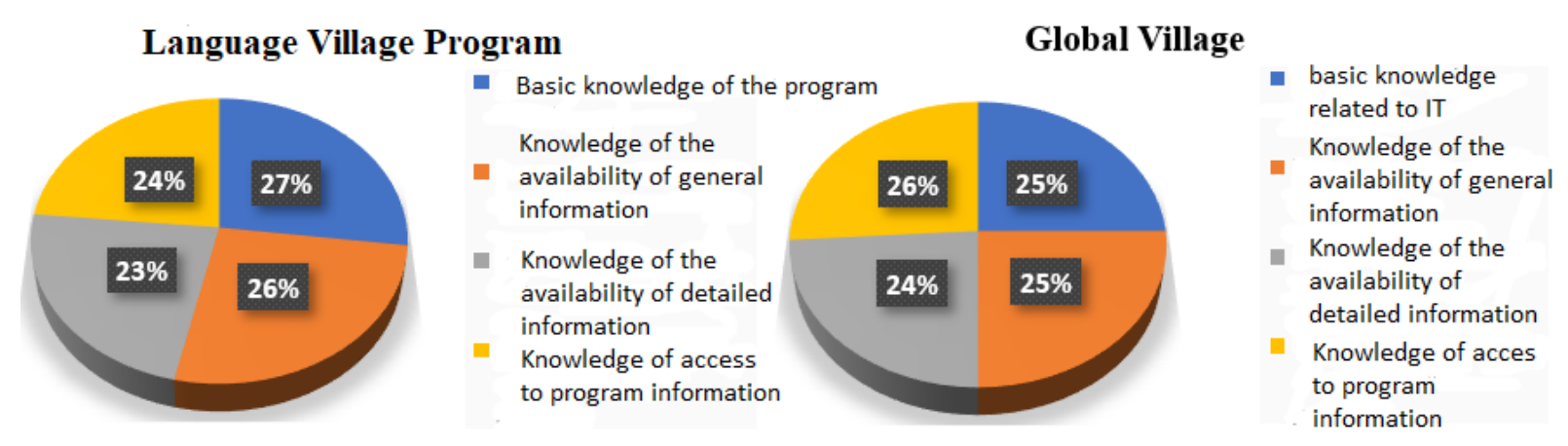

Figure 2. Percentage of Public Awareness

Source: Data processed by researchers, 2020

In Figure 2, the percentage of the four indicators, both in the tourism aspect of the language village and the global village, has a score that is almost balanced with a range between $23 \%-27 \%$. The language village's tourism aspect has the highest score of $27 \%$ on the basic knowledge indicator. Meanwhile, the lowest score is in the knowledge on the availability of detailed information indicator with a score of $23 \%$. These results indicate that the people of Ngargogondo Village do not sufficiently know the details regarding the Language Village program. Furthermore, in the global village aspect, the four indicators have almost the same value. Thus, the people of Ngargogondo Village are aware of the information technology issue, which is useful for establishing a global village.

The extent to which the community is aware of the issue is vital to the program implementation planning process. Community involvement and success in interpreting issues will help create intervention strategies and relevant steps to address these issues (Kostadinov et al., 2015; Shadowen et al., 2017). Concerning the global village, which is defined as the era of globalization (Sundararajan, 2010; Gibson and Murray, 2012; Nasution, 2016), the tourism sector would develop in the era of globalization if several factors can be adequately identified such as tourism potential, tourism readiness, infrastructure, and institutions as the supporting 


\section{Jurnal Ilmu Sosial Volume 19 | Issue 1| June 2020 | Page 58-91}

capacity for tourism development (Murdyastuti, 2017). Thus, in the context of the formation of a global village in the tourism sector, public knowledge of issues must be identified first because this is the first step in assessing the readiness of the community to come up with new policy intervention strategies or developing the existing interventions (McElroy et al., 2011; Kelly and Stanley, 2014).

\section{b. Community Knowlede on the Efforts}

The level of public knowledge about ongoing efforts is measured using three indicators, including basic knowledge of program implementation efforts, general knowledge of program implementation efforts, and detailed knowledge of program implementation efforts as shown in $\begin{array}{lllll}\text { Figure } & \text { (Plested al., et } & \text { 2006). }\end{array}$

Language Village Program

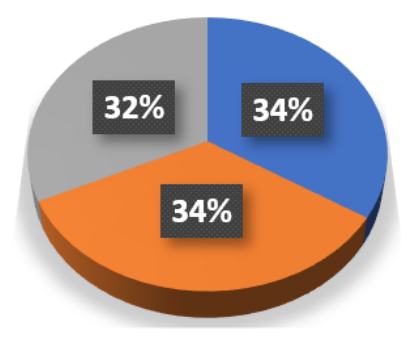

- Basic knowledge of the efforts

- General knowledge of the efforts

Detailed knowledge of the efforts
Global Village

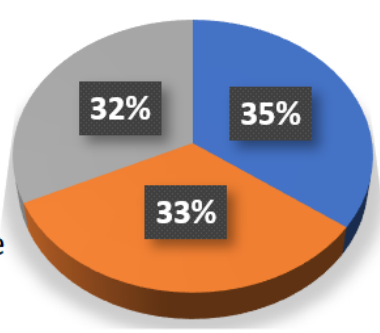

- Basic knowlege of the efforts General

- knowledge of the efforts Detailed knowledge of the efforts

Figure 3. Percentage of Knowledge on the Efforts

Source: Data processed by researchers, 2020

Figure 3 explains that in both the language village tourism aspect and the global village aspect, the dominant indicator is the community's basic knowledge towards ongoing efforts to develop or manage existing programs. However, the people of Ngargogondo Village do not know in detail what efforts have been made in developing the language village program and information technology to form a global village. Based on the results of the score analysis or the community readiness level score, the dimension of community knowledge about ongoing efforts has a high score but is not higher compared to other dimensions (table 5 and table 7). Based on interviews in the field, several people who became research informants stated that they knew about the language village program and information technology (global village) but did not know in detail regarding these issues. These findings reflect their knowledge related to ongoing efforts of this program. However, public knowledge regarding issues and ongoing efforts can be 


\section{Jurnal Ilmu Sosial Volume 19 | Issue $1 \mid$ June 2020 | Page 58-91}

improved by providing follow-up interventions in the program regardless of whether there has been previous intervention or not (Slater et al., 2005).

\section{c. Community Efforts}

Measurement of community efforts in the tourism aspects of the Language Village and global village programs is carried out using four indicators, including the existence of implementation efforts related to the program, the continuity of implementation efforts related to the program, the existence of planning development efforts related to the program, and the existence of program-related implementation policies (Plested et al., 2006). The score percentage of these indicators can be seen in Figure 4.
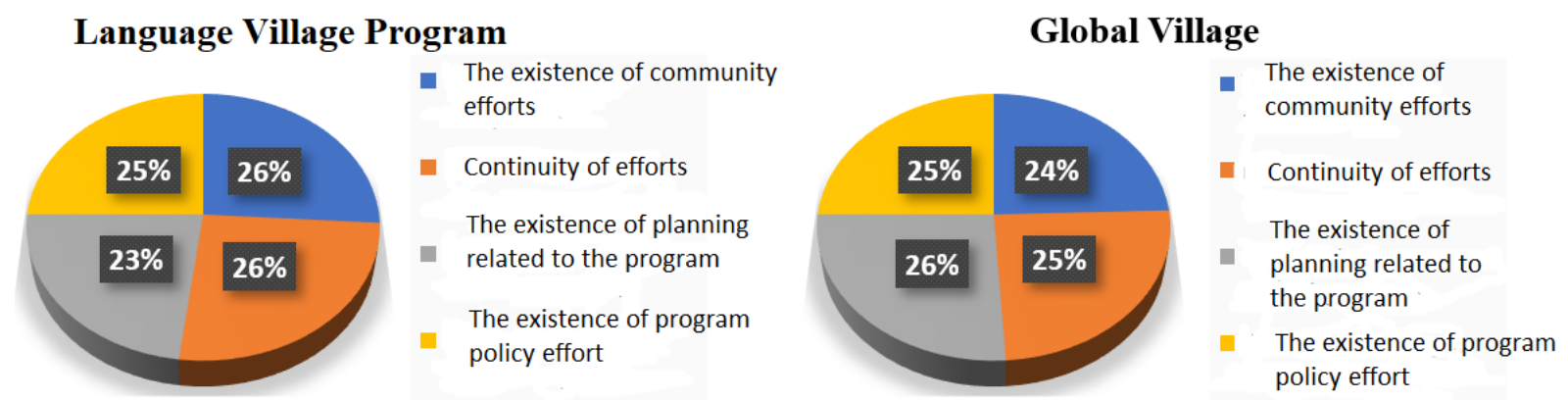

Figure 4. Percentage of Community Efforts

Source: Data processed by researchers, 2020

In the tourism aspect of the language village, the community has made efforts to support the language village program, and it has been carried out continuously (26\%). An example of community support is the establishment of a homestay adjacent to the language village location. On the one hand, the existence of a language village fosters local entrepreneurial potential, provides financial benefits, and supports the economy for local communities (Wijaya et al., 2020) through homestay rentals. On the other hand, community support provides benefits for the language village program's sustainability even though this support is not in the realm of Language Village management. These findings indicate that there is a mutually beneficial relationship for both parties (the community and the language village manager).

Furthermore, in the global village aspect, community efforts have reached the planning stage $(26 \%)$. As the definition and formation of a global village in several articles previously quoted, a global village is defined as a global village with the support of technology to inform other parts of the world. McLuhan stated that information and communication technology 


\section{Jurnal Ilmu Sosial Volume 19 | Issue 1 | June 2020 | Page 58-91}

changed the world into a big village or global village (Trembley, 2012). Consequently, information technology support is a significant factor in establishing a global village (Johnson, 2000; Magio, 2008; Andung et al., 2008; Pamungkas, 2015; Nasution, 2016). In this regard, the community's efforts to form a global village in the tourism sector in Ngargogondo Village have been implemented by creating a website containing the Language Village program (Figure 1). This website's existence indicates that there are planned efforts to promote and demonstrate the language village program to the global community.

\section{d. Leadership}

Leadership is included in the community readiness dimension using three indicators, including the level of awareness of village leaders regarding the program, the level of support from village leaders regarding the program, the level of involvement of village leaders regarding the program. The percentage of these indicators can be seen in Figure 5 (Plested et al., 2006).
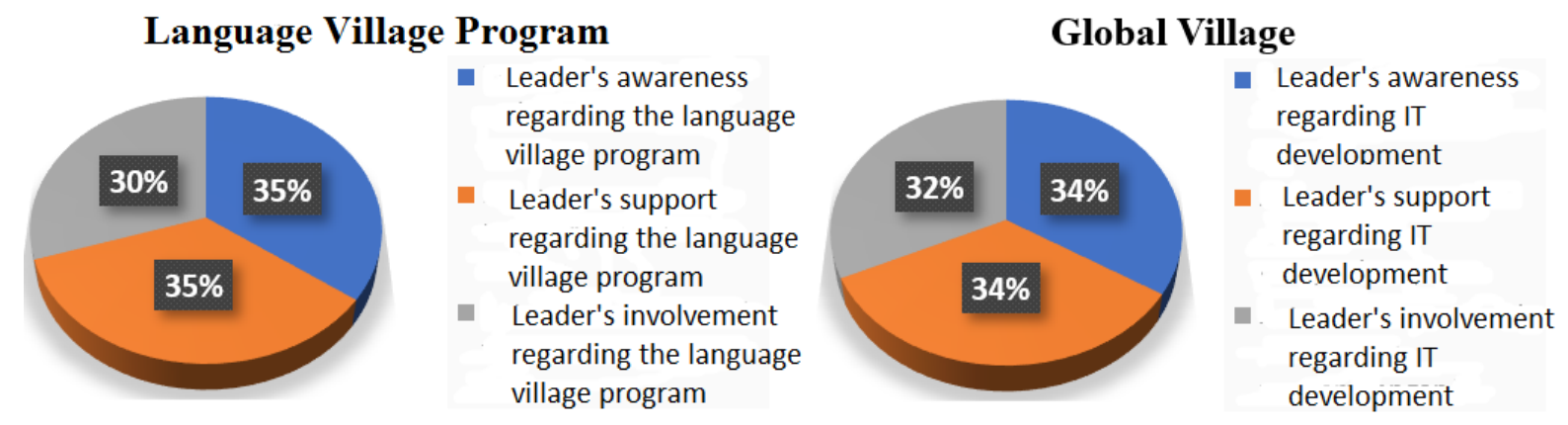

Figure 5. Percentage of Leadership

Source: Data processed by researchers, 2020

Figure 5 shows that the level of awareness and support of village leaders related to the development of language villages has the same score of $35 \%$, while the level of involvement of leaders in developing language villages is $30 \%$. In the global village aspect, the leaders of Ngargogondo Village have a high level of awareness and support (34\%) for information technology development issues, while the level of involvement is $32 \%$. This finding explains that the village leaders of Ngargogondo Village are aware of and support the two programs but need to get involved further in developing the language village and global village tourism. Leaders' support and involvement are factors in determining the level of community readiness (Kostadinov et al., 2015). 


\section{Jurnal Ilmu Sosial Volume 19 | Issue 1 | June 2020 | Page 58-91}

As an illustration, Kelly and Stanley's (2014) research on alcohol use prevention programs at several universities indicates that leaders' active involvement can increase the readiness of the university in running the existing programs.

As an influential figure, the leader directs the community in planning programs effectively (McElroy et al., 2011). We expect a high percentage of leader's involvement, among other indicators, but the results show that the leader's involvement is still relatively weak. However, the overall score of the leadership dimension is not too bad, or in other words, it has a fairly good score among the other dimensions.

\section{e. Community Climate (Attitude and Support)}

The community climate is actualized in community attitudes and support for the Language Village and global village programs. The measurement of community climate uses two indicators, including community attitudes towards the program, and various kinds of community support to the program (Plested et al., 2006; Boquiren, 2018). The percentage of these indicators can be seen in Figure 6.

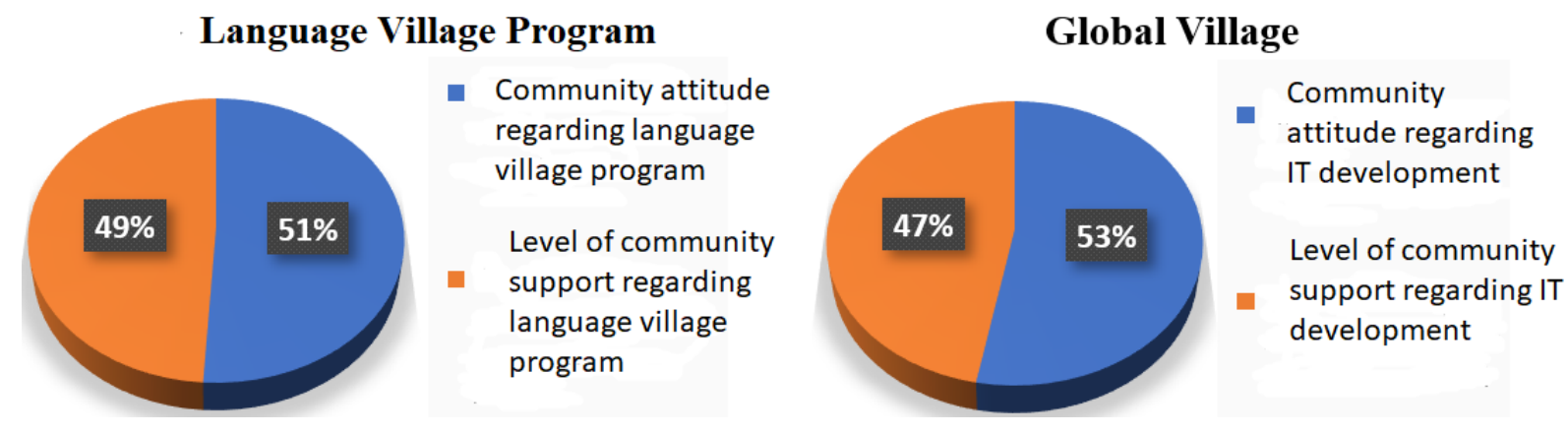

Figure 6. Percentage of Community Climate

Source: Data processed by researchers, 2020

Based on the data in Figure 6, all indicators have almost the same score on the tourism aspect of the language village and global village, between $47 \%-53 \%$. The dominant indicator in the community climate dimension is the community's attitude in supporting the Language Village program and global village development. Meanwhile, the level of support still tends to be low. Based on data in the field, the people of Parakan Hamlet tend to have a higher level of support compared to other hamlets even though they are still in one village. It is because Parakan Hamlet is the location of the Language Village. The positive impact of tourism activities can be 


\section{Jurnal Ilmu Sosial Volume 19 | Issue 1| June 2020 | Page 58-91}

in the form of increased financing, product expansion, socio-economy, natural environment protection (Kumar et al., 2015; Kozhokulov et al., 2019; Zaei and Zaei, 2013).

Parakan Hamlet is the only hamlet that receives the most significant impact, especially the welfare of the community. Thus, it is very reasonable that the level of community support in Parakan Hamlet for the language village is very high. However, when compared with the overall score of each dimension, the community climate in both aspects (discussion village and global village) has a small score or score compared to other dimensions (tables 5 and 7), especially in the global village aspect, which ranks the smallest than the other dimensions with a score of 7.3.

\section{f. Resources}

Resources are measured using three indicators, including the availability of village resources related to the program, the allocation of village resources related to the program, and the level of village resource needs related to the program as can be seen in Figure 7 (Plested et al., 2006;

Pratama and

Wulandari,

2019).

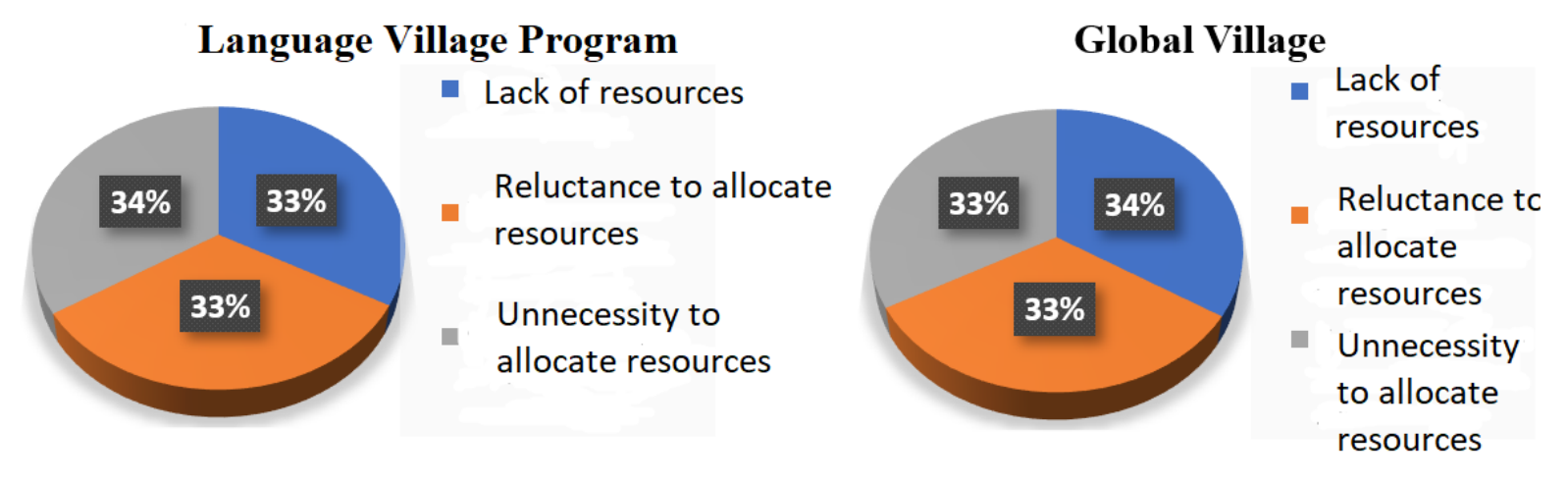

Figure 7. Percentage of Resources

Source: Data processed by researchers, 2020

The indicator of unwillingness to maximize resources in the language village's tourism aspect has the most dominant percentage at $34 \%$. In this case, resources such as financial, human resources, and property are available. However, the main question is, why do people feel there is no need to maximize resources? In reality, this attitude makes the resource dimension has the smallest score among the other dimensions in the language village aspect at 6.6 (table 5). These findings strengthen Kelly and Stanley's (2014) argument that the high value or score of the resource dimension reflects a willingness to allocate and maximize resources, and vice versa. 


\section{Jurnal Ilmu Sosial Volume 19 | Issue 1| June 2020 | Page 58-91}

Meanwhile, in the global village aspect, the indicator of lack of resources has a higher percentage than other indicators, namely $34 \%$. If we look at table 6 , the resource dimension is in the second smallest position after the community climate dimension. Even though the community's efforts to establish a global village have been running with the website's existence, it is undeniable that the resources to form a global village in Ngargogondo Village are still minimal, especially human resources that capable of operating information technology.

\section{Level of Community Readiness in Establishing a Global Village Tourism Sector}

After the percentage assessment of each dimension has been produced, the next step is to assess community readiness level in each aspect. That way, it can be seen at what level and which dimension of community readiness has the highest and lowest scores in establishing a global village in the tourism sector.

The first step in determining the level of community readiness is adding the weighted scores for each indicator based on a scoring scale of 1-5, ranging from strongly disagree to strongly agree (Sugiharto et al., 2018; Kurniati et al., 2014; Shadowen, 2017; Nurazizah and Darsiharjo, 2018; Pratama and Wulandari, 2019). After the total score for each indicator is generated, the next step is to add up the score of the indicator according to each variable and divided by 157 respondents to get the score of each variable or dimension as in Table 5 . 


\section{Jurnal Ilmu Sosial Volume 19 | Issue 1| June 2020 | Page 58-91}

Table 5. The Score of Community Readiness Variable Aspects of Language Village Tourism

Variable

CKI Basic knowledge regarding Language Village program

Knowledge of information availability

Knowledge of the availability of detailed information

Knowledge of access to information

CKE Basic knowledge of efforts to implement the Language

Village program

General knowledge of efforts to implement the Language Village program

Detailed knowledge of the efforts to implement the Language Village program

CE The existence of community efforts related to the 529 Language Village program

Continuity of efforts related to the Language Village program

The existence of a plan regarding the Language 481

Village program

The existence of policy support related to the 518 Language Village program

L Village leaders' awareness regarding the Language 583 Village program

Support from village leaders regarding the Language

Village program

The involvement of village leaders regarding the 503 Language Village program
Score/number

of respondents

14

(highest score)

512

499

9.3

498

469 


\begin{tabular}{lcc}
\hline Variable Indicator & Score & $\begin{array}{c}\text { Score/ } \\
\text { number of } \\
\text { respondents }\end{array}$ \\
\hline
\end{tabular}

$\begin{array}{llll}\text { CC } & \text { Community attitudes regarding the Language Village } & 637 & 8\end{array}$ program

Community support related to the Language Village 630 program

$\mathrm{R}$ The absence of village resources related to the 341 6.6 Language Village program

Reluctance to allocate village resources related to the 348 Language Village program (lowest score)

The need to maximize village resources related to the 356 Language Village program

Source: Data processed by researchers, 2020

The next step is to calculate the score of community readiness for the aspects of language village tourism using the following formula (Kurniati et al., 2014):

$$
\begin{aligned}
\mathrm{PKM} & =(\mathrm{K} 1+\mathrm{K} 2+\mathrm{K} 3+\mathrm{K} 4+\mathrm{K} 5+\mathrm{K} 6) / 6 \\
& =14+9.3+13.21+10.6+8+6.6=61.71(\text { rounding of } 62) \\
\mathrm{PKM} & =62 / 6=\mathbf{1 0 . 3}
\end{aligned}
$$

After that, the score interval is calculated from each level of community readiness obtained from reducing the highest score against the lowest score of the community readiness variable score and divided by nine levels of community readiness (Kurniati et al., 2014).

$$
\begin{aligned}
\text { Interval } & =14-6.6=7.4 \\
& =7.4 / 9=0.82(\text { rounding of } \mathbf{0 . 8})
\end{aligned}
$$




\section{Jurnal Ilmu Sosial Volume 19 | Issue 1| June 2020 | Page 58-91}

Based on these calculations results, an interval score of 0.8 was obtained, which was used to create a table of community readiness levels and was juxtaposed with the community readiness scores listed in Table 6.

Table 6. The Level of Community Readiness of Language Village Tourism Aspect

\begin{tabular}{lcc}
\hline No & Level & Nilai Skor \\
\hline $\mathbf{1}$ & No awareness & $6.6-7.4$ \\
$\mathbf{2}$ & Denial/resistance & $7.5-8.3$ \\
$\mathbf{3}$ & Vague awareness & $8.4-9.2$ \\
$\mathbf{4}$ & Preplanning & $9.3-10.1$ \\
$\mathbf{5}$ & Preparation & $\mathbf{1 0 . 2}-\mathbf{1 1}$ \\
$\mathbf{6}$ & Initiation & $11.1-11.9$ \\
$\mathbf{7}$ & Stabilization & $12-12.8$ \\
$\mathbf{8}$ & Confirmation/expansion & $12.9-13.7$ \\
$\mathbf{9}$ & High level of community ownership/professionalization & $13.8-14.6$ \\
& & \\
\hline
\end{tabular}

Source: Data processed by researchers, 2020

From the previous calculation, the community readiness score was 10.3 . Referring to the table above, the level of readiness of the Ngargogondo Village community in the tourism aspect of the Language Village is in the preparation stage (fifth position), which means that the leader plays an active role in designing planning seriously, with the simple support of the village community (Edwards et al., 2000; Plested et al., 2006; McElroy et al., 2011; Paltzer et al., 2013; Tri-Ethnic Center, 2014; Islam et al., 2019). Re-highlighting the leadership dimensions of the Language Village's tourism aspect, the score was found to be 10.6. With this score, the leadership dimension is in fourth place from all dimensions. In this regard, the community readiness stage can be increased to a higher stage if the leaders wish to involve themself, not only support the program (Kostadinov et al., 2015; Kelly and Stanley, 2014). Through the involvement of leaders and their influence, community support can be further increased to achieve the effectiveness of the language village program (McElroy et al., 2011). 


\section{Jurnal Ilmu Sosial Volume 19 | Issue 1| June 2020 | Page 58-91}

Furthermore, determining the level of community readiness in the global village aspect, the stages and formulas used to calculate variable scores, community readiness scores, and interval scores are the same as before (Sugiharto et al., 2012; Kurniati et al., 2015; Shadowen, 2017; Nurazizah and Darsiharjo, 2018; Pratama and Wulandari, 2019). The following are the variable scores in the global village aspect as can be seen in Table 7. 


\section{Jurnal Ilmu Sosial Volume 19 | Issue $1 \mid$ June 2020 | Page 58-91}

Table 7. The Variable Score for Community Readiness of Global Village Aspect

\begin{tabular}{|c|c|c|c|}
\hline Variable & Indicator & Score & $\begin{array}{c}\text { Score/ } \\
\text { number of } \\
\text { respondents }\end{array}$ \\
\hline \multirow[t]{4}{*}{ CKI } & $\begin{array}{l}\text { Basic knowledge of information technology } \\
\text { development }\end{array}$ & 436 & $\begin{array}{l}11.1 \text { (highest } \\
\text { score) }\end{array}$ \\
\hline & Knowledge of information availability & 441 & \\
\hline & Knowledge of the availability of detailed information & 429 & \\
\hline & Knowledge of access to information & 449 & \\
\hline \multirow[t]{3}{*}{ CKE } & $\begin{array}{l}\text { Basic knowledge of information } \\
\text { development efforts }\end{array}$ & 457 & 8.1 \\
\hline & $\begin{array}{l}\text { General knowledge of information technology } \\
\text { development efforts }\end{array}$ & 418 & \\
\hline & $\begin{array}{l}\text { Detailed knowledge of information technology } \\
\text { development efforts }\end{array}$ & 408 & \\
\hline \multirow[t]{4}{*}{$\mathrm{CE}$} & $\begin{array}{l}\text { The existence of community efforts regarding } \\
\text { information technology development }\end{array}$ & 396 & 10.2 \\
\hline & $\begin{array}{l}\text { Continuity of efforts regarding information technology } \\
\text { development }\end{array}$ & 395 & \\
\hline & $\begin{array}{l}\text { The existence of planning regarding information } \\
\text { technology development }\end{array}$ & 409 & \\
\hline & $\begin{array}{l}\text { The existence of policy support regarding information } \\
\text { technology development }\end{array}$ & 410 & \\
\hline \multirow[t]{3}{*}{$\mathrm{L}$} & $\begin{array}{l}\text { Village leaders' awareness regarding information } \\
\text { technology development }\end{array}$ & 509 & 9.5 \\
\hline & $\begin{array}{l}\text { Support from village leaders regarding information } \\
\text { technology development }\end{array}$ & 510 & \\
\hline & $\begin{array}{l}\text { The involvement of village leaders regarding information } \\
\text { technology development }\end{array}$ & 477 & \\
\hline
\end{tabular}




\begin{tabular}{|c|c|c|c|}
\hline Variable & Indicator & Score & $\begin{array}{l}\text { Score/number } \\
\text { of respondents }\end{array}$ \\
\hline \multirow[t]{2}{*}{$\mathrm{CC}$} & $\begin{array}{l}\text { Public attitudes regarding information technology } \\
\text { development }\end{array}$ & 608 & $\begin{array}{l}7.3 \text { (lowest } \\
\text { score) }\end{array}$ \\
\hline & $\begin{array}{l}\text { Community support regarding information technology } \\
\text { development }\end{array}$ & 547 & \\
\hline \multirow[t]{3}{*}{$\mathrm{R}$} & $\begin{array}{l}\text { Lack of village resources regarding information } \\
\text { technology }\end{array}$ & 394 & 7.4 \\
\hline & $\begin{array}{l}\text { Reluctance to allocate village resources related to } \\
\text { information technology development }\end{array}$ & 391 & \\
\hline & $\begin{array}{l}\text { Unwillingness to maximize village resources related to } \\
\text { information technology development }\end{array}$ & 387 & \\
\hline
\end{tabular}

Source: Data processed by researchers, 2020

Meanwhile, the global village aspect of community readiness score interval is 0.4 which is obtained from the following calculations:

$$
\begin{aligned}
\text { Interval } & =11.1-7.3=3.8 \\
& =3.8 / 9=0.42(\text { rounding of } \mathbf{0 , 4})
\end{aligned}
$$

Based on the interval score of 0.4 , the level of community readiness in the global village aspect can be seen in Table 8 . 
Jurnal Ilmu Sosial Volume 19 | Issue $1 \mid$ June 2020 | Page 58-91

Table 8. The Level of Community Readiness of Global Village Aspect

\begin{tabular}{lcc}
\hline No & Level & Score \\
\hline $\mathbf{1}$ & No awareness & $7.3-7.7$ \\
$\mathbf{2}$ & Denial/resistance & $7.8-8.2$ \\
$\mathbf{3}$ & Vague awareness & $8.3-8.7$ \\
$\mathbf{4}$ & Pre-planning & $\mathbf{8 . 8}-\mathbf{9 . 2}$ \\
$\mathbf{5}$ & Preparation & $9.3-9.7$ \\
$\mathbf{6}$ & Initiation & $9.8-10.2$ \\
$\mathbf{7}$ & Stabilization & $10.3-10.7$ \\
$\mathbf{8}$ & Confirmation/expansion & $10.8-11.2$ \\
$\mathbf{9}$ & High level of community ownership/professionalization & $11.3-11.7$ \\
\hline
\end{tabular}

Source: Data processed by researchers, 2020

Referring to the table above and the community readiness score of 8.9, the level of readiness of the Ngargogondo Village community in the global village aspect is in the preplanning stage (fourth position), which means that the community is aware and acknowledges that there is an issue or problem being faced, must take some preventive efforts or countermeasures, but these efforts have not been focused in detail (Edwards et al., 2000; Plested et al., 2006; McElroy et al., 2011; Paltzer et al., 2013; Tri-Ethnic Center, 2014; Islam et al., 2019). Each dimension's score in the global village aspect tends to be smaller than the Language Village aspect's score. This result is due to the lack of public knowledge about information technology and its use in establishing a global village. Thus, it also impacts other dimensions, even though public knowledge of information technology issues must be identified first to lead to further policy interventions (McElroy et al., 2011; Kelly and Stanley, 2014). 


\section{Jurnal Ilmu Sosial Volume 19 | Issue 1| June 2020 | Page 58-91}

\section{CONCLUSION}

Based on the results of the analysis, it can be concluded that the level of readiness of the people of Ngargogondo Village, Borobudur Subdistrict, Magelang Regency, Central Java in realizing the global village tourism sector is at the preparation level (language village tourism aspect) and pre-planning (global village aspect). The findings in this study are on the aspect of language village tourism. The highest scoring dimension is public knowledge regarding the issue with a score of 14 , while the smallest is resources with a score of 6.6. Furthermore, the highest dimension from the global village aspect is the dimension of public knowledge regarding the issue with a score of 11.1, and the smallest is the community climate dimension with a score of 7.3. Several things that must be considered to improve community readiness and realize a global village in the tourism sector are increasing the availability of resources, especially in the tourism aspects of the Language Village program, and creating a positive climate in the community in response to the development of information technology.

\section{ACKNOWLEDGEMENT}

Our appreciation and gratitude to Tidar University for funding this research so that it can be completed in a timely manner, as well as the people of Ngargogondo Village for assisting in the data collection process.

\section{BIBLIOGRAPHY}

Andung, Petrus Ana, Dian Wardiana Sjuchro, Aloysius Liliweri, and Purwanti Hadisiwi.(2018). Television as a Symbolic Culture: A Media Ethnography Study of the Border Communities of Indonesia-Timor Leste. Teorija In Praksa, 55(2):328-344, [Online].

Arikunto, S. (2001). Dasar Dasar Evaluasi Pendidikan. Jakarta: Bina Aksara.

Barrientos, Armando and Daniel Neff. (2011). Attitudes to Chronic Poverty in the Global Village. Social Indicators Research, 100(1):101-114 (doi: 10.1007/s11205-010-9606-7), [Online].

Borobudur Language Village [online]. Retrieved from www.desa-bahasa.com [Accessed November 30, 2019] 


\section{Jurnal Ilmu Sosial Volume 19 | Issue 1| June 2020 | Page 58-91}

Boquiren. A.A.S. (2018). Community Readiness Assessment for a Community-Based Collecting and Archiving Project for Contemporary Komiks. Journal of Philippine Librarianship, 38:1-17, [Online].

Chaplin, J. (2006). Kamus Lengkap Psikologi. Jakarta: PT. Raja Grafindo Persada

Edwards, Ruth W., Pamela Jumper-Thurman, Barbara A. Plested, Eugene R. Oetting, Louis Swanson. (2000).Community readiness: Research to practice. Journal of Community Psychology, 28(3):291-307 (doi : 10.1002/(SICI)1520-6629(200005)28:3<291::AIDJCOP5>3.0.CO;2-9), [Online].

Gibson, T. and S.J. Murray. (2012). "Global Village" in M. Danesi (Ed.), Encyclopedia of Media and Communication. Toronto: University of Toronto: pp. 312-313.

Indiarti, Wiwin and Abdul Munir. (2016). The Implementation of Community-Based Ecotourism Concept in Osing Tourism Village Development Strategy of Banyuwangi Regency, Indonesia. at Proceeding of the Asia Tourism Forum 2016-The 12 ${ }^{\text {th }}$ Biennial Conference of Hospitality and Tourism Industry in Asia, 68-73. Bandung: The $12^{\text {th }}$ Biennial Conference of Hospitality and Tourism Industry in Asia, (doi: 10.2991/atf-16.2016.10), [Online].

Islam, Shahid, Neil Small, Maria Bryant, Sally Bridgers, Nicola Hancock, and Josie Dickerson. (2019). Assessing Community Readiness for Early Intervention Programmes to Promote Social and Emotional Healt in Children. Health Expectations, 22(3):575-584 (doi: 10.1111/ hex.12887), [Online].

Johnson, Brian. (2000). Plastic Shaman in the Global Village: Understanding Media in Thomas King's Green Grass, Running Water. Studies in Canadian Literature, 25(2):24, [Online].

Kelly, Kathleen J., and Linda Stanley. (2014). Identifying Upstream Factors Using the Community Readiness Model. Journal of Social Marketing, 4(2):176-191 (doi: 10.1108/ JSOCM-08-2013-005), [Online].

Kismartini, Hendra Kurniawan, and Septi Anjani Putri Dwika. (2018). Strategi Pengembangan Banjir Kanal Barat Sebagai Daya Tarik Wisata di Kota Semarang. Jurnal Ilmu Sosial, 17 (1):64-76 (doi: 10.14710/jis.17.1.2018.64-76), [Online].

Kostadinov, Iordan, Mark Daniel, Linda Stanley, Agustina Gancia, and Margaret Cargo. (2015). A Systematic Review of Community Readiness Tool Aplications: Implications for Reporting. International Journal Environmental Research and Public Health, 12(4):34533468 (doi: 10.3390/ijerph120403453), [Online]. 


\section{Jurnal Ilmu Sosial Volume 19 | Issue 1| June 2020 | Page 58-91}

Kelly, Kathleen J., and Linda Stanley. (2014). Identifying Upstream Factors Using the Community Readiness Model. Journal of Social Marketing, 4(2):176-191 (doi: 10.1108/ JSOCM-08-2013-005), [Online].

Kismartini, Hendra Kurniawan, and Septi Anjani Putri Dwika. (2018). Strategi Pengembangan Banjir Kanal Barat Sebagai Daya Tarik Wisata di Kota Semarang. Jurnal Ilmu Sosial, 17 (1):64-76 (doi: 10.14710/jis.17.1.2018.64-76), [Online].

Kostadinov, Iordan, Mark Daniel, Linda Stanley, Agustina Gancia, and Margaret Cargo. (2015). A Systematic Review of Community Readiness Tool Aplications: Implications for Reporting. International Journal Environmental Research and Public Health, 12(4):34533468 (doi: 10.3390/ijerph120403453), [Online].

Kozhokulov, Sadyrbek, Xi Chen, Degang Yang, Gulnura Issanova, Kanat Samarkhanov, and Selvina Aliyeva. (2019). Assessment of Tourism Impact on the Socio-Economic Spheres of the Issyk-Kul Region (Kyrgyzstan). Sustainability, 11(14):1-18 (doi: 10.3390/ su11143886), [Online].

Kumar, Jeetesh, Kashif Hussain, and Suresh Kannan. (2015). Positive vs Negative Economic Impacts of Tourism Development: A Review of Economic Impact Studies. Dalam ConferenceProceedings Developments of the New Tourism Paradigm in the Asia Pacific Region. Kuala Lumpur: 21 ${ }^{\text {st }}$ Asia Pacific Tourism Association Annual Conference, [Online].

Kurniati, Eti, Christia Meidiana, and Agus Dwi Wicaksono. (2014). Kajian Kesiapan Masyarakat Terkait Rencana Kegiatan Industri Pertambangan Marmer (Studi Kasus di Kelurahan Oi Fo'o Kota Bima-NTB). The Indonesian Green Technology Journal, 4(1):18-27. [Online].

Law Number 10 of 2009 concerning Tourism.

Magio, Nicole. (2008). The Whole Earth as Village: a Chronotopic Analysis of Marshall Mcluhan's Global Village and Patrick McGoohan's The Prisoner. Postgraduate Thesis. Brock University.

Maschab, M. (2013).Politik Pemerintahan Desa di Indonesia. Yogyakarta: Research Center for Politics and Government. 


\section{Jurnal Ilmu Sosial Volume 19 | Issue 1| June 2020 | Page 58-91}

McElroy, Theresa A., Alexis Davis, Cynthia Hunt, Jigmet Dadul, Tsering Stanba, and Charles Larson. (2011). Navigating a Way Forward: Using Focused Ethnography and Community Readiness to Study Disability Issues in Ladakh, India. Disability and Rehabilitation, 33 (1):17-27 (doi: 10.3109/09638288.2010.485670), [Online].

McLuhan, Marshal. (1962). The Making of Typographic Man. New York: McGraw-Hill.

Michael, Antecol. (1999). Abstracting the Later McLuhan: Television's Cool Role in the Creation of the Global Village. Canadian Journal of Communication, 24(2):199-219 (doi: 10.22230/cjc.1999v24n2a1096), [Online].

Molinaro, M., C. McLuhan, and W. Toye. (Eds.). (1987). Letters of Marshall McLuhan. Toronto: Oxford University Press

Muhammad. (2015). Tingkat Kesiapan Masyarakat Pengelolaan Lingkungan dan Kepariwisataan Alam Pasca-Erupsi 2010. Kawistara, 5(2):99-220 (doi: 10.22146/kawistara.7586), [Online].

Murdyastuti, Anastasia. (2017). Institutional Development of Osing Tourism Area to Face of Globalization. Public Policy and Administration Research, 7(10):73-81, [Online].

Nasution, R.D. (2016). Pengaruh Kesenjangan Digital Terhadap pembangunaan Pedesaan (Rural Development). Jurnal Penelitian Komunikasi dan Opini Publik, 20(1):31-44, [Online].

Nugraha, Dimas Hastama and Masmian Mahida. (2013). Kesiapan Masyarakat Menerapkan Teknologi Tepat Guna Pengolahan Air Minum (Studi Kasus: Pulau Palu'e, Nusa Tenggara Timur). Jurnal Sosek Pekerjaan Umum, 5(2):76-139, [Online].

Nurazizah, Ghoitsa Rohmah and Darsiharjo. (2018). Kesiapan Masyarakat Desa Wisata di Kampung Seni dan Budaya Jelekong Kabupaten Bandung. Jurnal Pendidikan Geografi, 18 (2):103-113 (doi: 10.17509/gea.v18i2.13524), [Online].

Paltzer, Jason, Penny Black, and D. Paul Moberg. (2013). Evaluating Community Readiness to Implement Environmental and Policy-Based Alcohol Abuse Prevention Strategies in Wisconsin. Journal of Alcohol and Drug Education, 57(3):27-50, [Online].

Pamungkas, Cahyo. (2015). Global Village dan Globalisasi dalam Konteks Ke-Indonesiaan. Global \& Strategis, 9(2):245-261 (doi: 10.20473/jgs.9.2.2015.245-261), [Online].

Phon-ngam, Patthira. (2014). Preparing the Readiness of Tourism Activities for Destinations Along the Mekong River to Become the ASEAN Community: A Case Study in Chiang Khan at Loei Province, Thailand. Journal of Social Sciences(COES\&RJ-JSS), 3(2):277285, [Online]. 


\section{Jurnal Ilmu Sosial Volume 19 | Issue $1 \mid$ June 2020 | Page 58-91}

Prasetyono, Agus Puji. (2017). "Membangun Desa, Membangun Daya Saing Indonesia" [online]. Retrieved from https://ristekdikti.go.id/kolom-opini/membangun-desamembangun-daya-saing-indonesia/ [Accessed November 30, 2019].

Pratama, Arif Budy and Catur Wulandari. (2019). Villager Readiness in Rural Tourism: a Scale Development Using Exploratory Factor Analysis. International Journal Tourism Policy, 9 (3):251-261 (doi: 10.1504/IJTP.2019.104887), [Online].

Press, L. (1995). McLuhan Meets the Net. Communications of the ACM, 38 (7):15-20 (doi: 10.1145/213859.214787), [Online].

Ramadhan, F.L. (2015). “Arahan Peningkatan Kesiapan Masyarakat terhadap Rencana Pembangunan Kawasan Industri di Kecamatan Wongsorejo Kabupaten Banyuwangi”. Skripsi. Institut Teknologi Sepuluh November.

Shadowen, Noel L., Nancy G. Guerra, Gabriela R. Rodas, and Rodrigo S. Berthet. (2017). Community Readiness for Youth Violence Prevention: a Comparative Study in the US and Bolivia. Vulnarable Children and Youth Studies, 12(2):117-129 (doi: 10.1080/17450128.2017.1286423), [Online].

Slameto. (2010). Belajar dan Faktor-Faktor yang Mempengaruhi. Yogyakarta: Andy Publisher

Slater, Michael.D., Ruth W. Edwards, Barbara A. Plested, Pamela J. Thurman, Kathleen J. Kelly, Maria Leonara G. Comello, and Thomas J. Keefe. (2005). Using Community Readiness Key Informant Assessments in a Randomized Group Prevention Trial: Impact of a Participatory Community-Media Intervention. Jurnal of Community Health, 30(1):39-53 (doi: 10.1007/s10900-004-6094-1), [Online].

Sugiharto, Fitria Delita, and Tumiar Sidauruk. (2018). Tingkat Kesiapan Masyarakat Lokal Terhadap Pengembangan Community Based Tourism (CBT) di Kabupaten Simosir. Jurnal Geografi, 10(2):157-163 (doi: 10.24114/jg.v10i2.10419), [Online].

Suh, Bernadyn K., and Francis A. Samuel. (2011). The Value of Multiculturalism in a Global Village: In the Context of Teaching Children's Literature. New England Readiing Association Journal, 47(1):1-10, [Online].

Sundararajan, K.R. (2010). Hinduisn and the Global Village. Religious Studies and Theology, 29 (1):81-92, (doi: 10.1558/rsth.v29i181), [Online].

The Republic of Indonesia Government Regulation Number 50 of 2011 concerning the National Tourism Development Master Plan Year 2010-2025. 


\section{Jurnal Ilmu Sosial Volume 19 | Issue 1| June 2020 | Page 58-91}

Thurman, Pamela J., Barbara A. Plested, Ruth W. Edwards, Robert Foley, and Martha Burnside. (2003). Community Readiness: The Journey to Community Healing. Journal of Psychoactive Drugs, 35(1):27- 31 (doi: 10.1080/02791072.2003.10399990), [Online]

Trembley, Gaetan. (2012). From Marshall McLuhan to Harold Innis, or From the Global Village to the World Empire. Canadian Journal of Communication, 37(4):561-575 (doi: 10.22230/ cjc.2012v37n4a2662), [Online].

Tri-Ethnic Center for Prevention Research. (2014). Community readiness for community change (2nd ed.) [online]. Retrieved from http://tec.wolpe2.natsci.colostate.edu/. [Accessed November 23, 2019]

Waryanto, Nur Hadi, and Nur Insani. (2013). Tingkat Kesiapan (Readiness) Implementasi ELearning di Sekolah Menengah Atas Kota Yogyakarta. Jurnal Pendidikan Matematika dan Sains, 1(2):117-124 (doi: 10.21831/jpms.v2i2.2478), [Online].

Wijaya, Putu Yudy, Putu Sri Hartati, and Ni Komang Sumadi. (2020). The Readiness of Community Based Tourism Village Development (Case Study at Bongkasa Pertiwi Tourism Village, Bali Province, Indonesia). Europian Journal of Business and Management Research, 5(3):1-5 (doi: 10.24018/ejbmr.2020.5.3.269), [Online].

Yusnawati. (2007). "Kesiapan Berwirausaha Siswa Jurusan Kecantikan SMKN”. Undergraduate Thesis. Universitas Negeri Yogyakarta.

Zaei, Mansour Esmaeil and Mahin Esmail Zaei. (2013). The Impacts of Tourism Industry on Host Community. Europian Journal of Tourism Hospitality and Research, 1(2):12-21, [Online]. 